\title{
A Research on Various Solar Thermal Power Technologies
}

\author{
Sonali Goel, Renu Sharma
}

\begin{abstract}
Solar thermal electric systems are simplest and hold promise of viability. Solar thermal systems have great similitude with conventional power system. In this paper we present an overview of various solar thermal power technologies to evolve criteria for selection of best systems.
\end{abstract}

Keywords:Solar thermal power technologies; Solar energy; Efficiency.

\section{INTRODUCTION}

India, mainly depends on fossil fuel based energy to fulfill its daily energy demand. It is the fourth largest consumer of electricity after China, USA and Russia [11]. Due to the increase in global warming and air pollution, it has become a great issue to increase the dependency on renewable energy sources. India has abundant sources of renewable energy mainly solar energy, wind energy and biomass. So non-conventional energy sources can be used to replace the conventional energy sources. So utilization of renewable energy resources especially solar energyeither solar photovoltaic or solar thermal can be used to generate electricity for sustainable development. India receives abundant of solar energy of about $4-7 \mathrm{kWh} / \mathrm{m} 2 /$ day .This energy can be converted into usable form of electricity by using different solar power technologies. Thereare mainly two important systems in solar thermal power technologies -solar collector and solar thermal energy storage. Solar collector is a device that collects heat from sun and absorbs it. It converts the solar energy to thermal energy or electrical energy for use in industries or commercial applications. Many authors across the globe conducted various studies on different types of solar thermal technologies and their applications[2][3][6][7][8].

\section{VARIOUS COMPONENTS OF SOLAR THERMAL POWER}

Solar energy is reliable but it is intermittent as it is not available at off sunshine period like cloudy days and night time. During the day time the solar energy can be converted to usable form of energy through solar thermal collector. The components of solar thermal systems are listed below.
A.Collector
B.Working Fluid
C.Prime mover

Revised Version Manuscript Received on 10 September, 2019.

SonaliGoel, Department of Electrical Engineering, Institute of Technical Education and Research, Siksha 'O' Anusandhan,Deemed to be University, Bhubaneswar, Odisha, India (Email: sonali19881@gmail.com)

Renu Sharma, Department of Electrical Engineering, Institute of Technical Education and Research, Siksha 'O' Anusandhan,Deemed to be University, Bhubaneswar, Odisha, India

\section{D.Generator}

E. Storage Device

F. Electrical Output

We are focusing on various types of collectors which are the costliest component of the system. There are four types of collectors:
A. Flat plate collectors
B.Focusing type of collectors
C. Parabolic trough
D. Central Tower

\section{A. Flat plate collectors}

Flat plate collectors (Fig-1) are designed for the temperature up to $70 \mathrm{0C}$. In this collector liquid ammonia can be used. We can produce power using Rankin cycle as shown in (Fig-2).Generally the absorber plate is coated with blackened surface in order to absorb as much heat as possible[5].

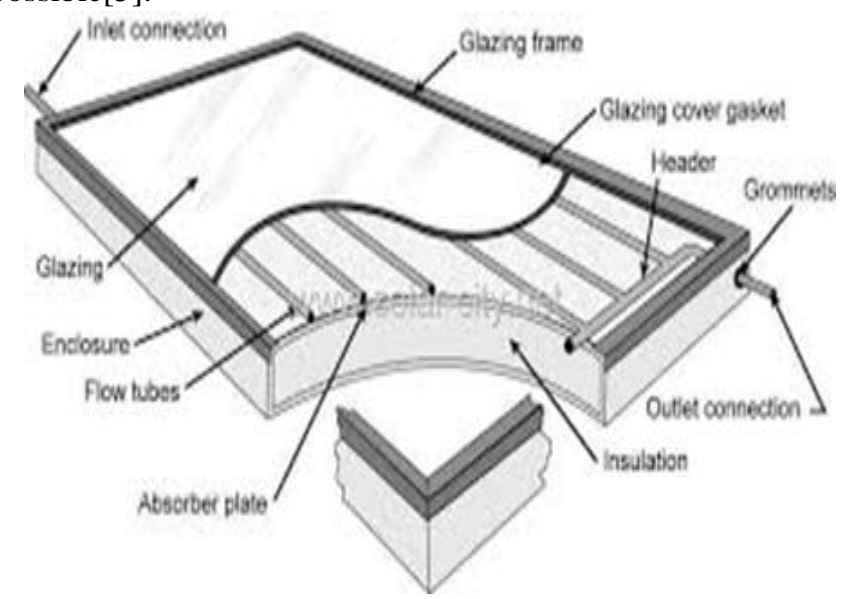

Fig.1 Flat plate collectors

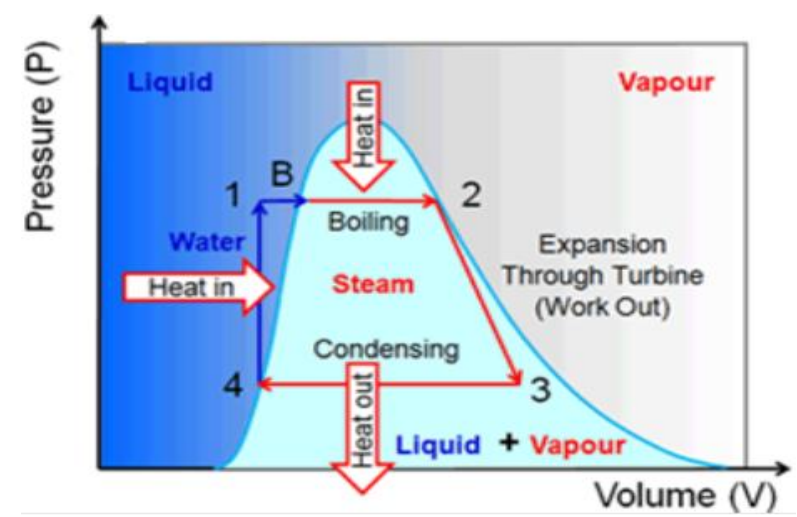

Fig.2 Ideal Rankin Heat cycle P-V diagram 


\section{B.Focusing collectors}

Focusing type of collectors are of two types i.e. line focusing collectors and point focusing collectors. Line focusing collectors are single axis tracking and focuses radiation along a line. Parabolic trough is an example of line focusing collectors.

\section{Parabolic dish collectors}

In parabolic dish collector, sunlight is focused by a dish (filled with high quality mirrors), (Fig-4\& Fig-5) to a point receiver where heat is produced. By this system temperature of around $300-5000 \mathrm{C}$ is produced. The heat is taken up by water flowing through tubes to convert it into steam for further use. Efficiency also depends on climatic condition and sun's intensity. Also, sterling engine (Fig-3) is used to harness power by heating the air and air is used as working fluid.

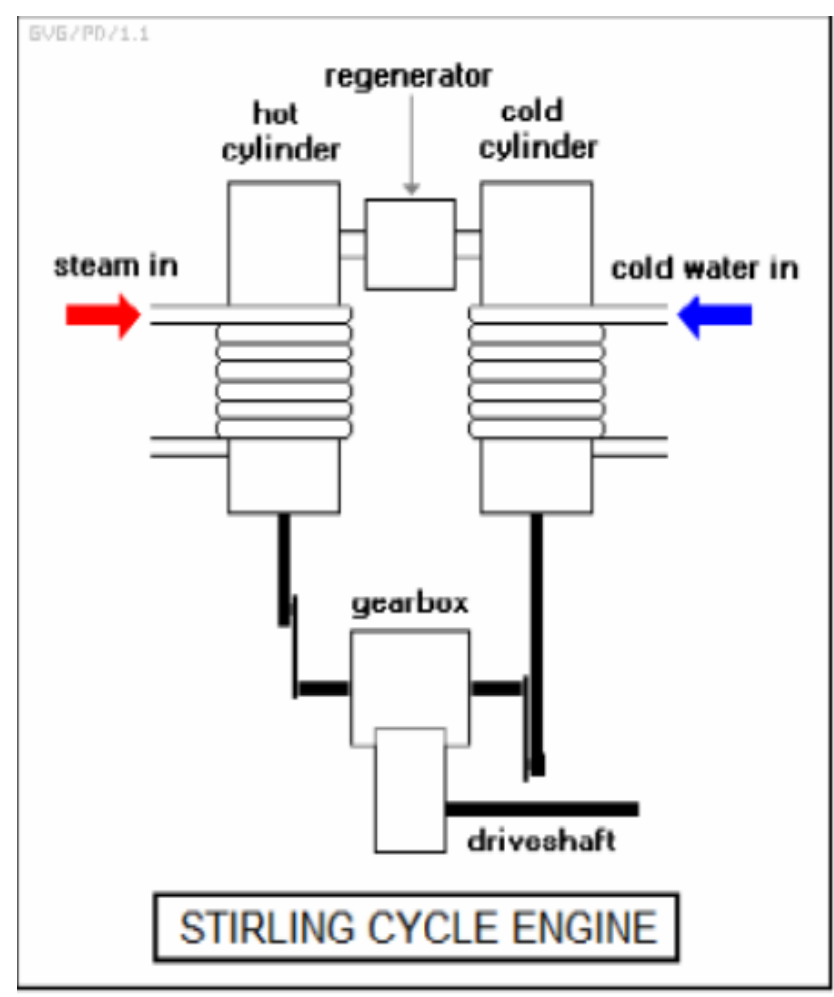

Fig.3 Sterling cycle engine

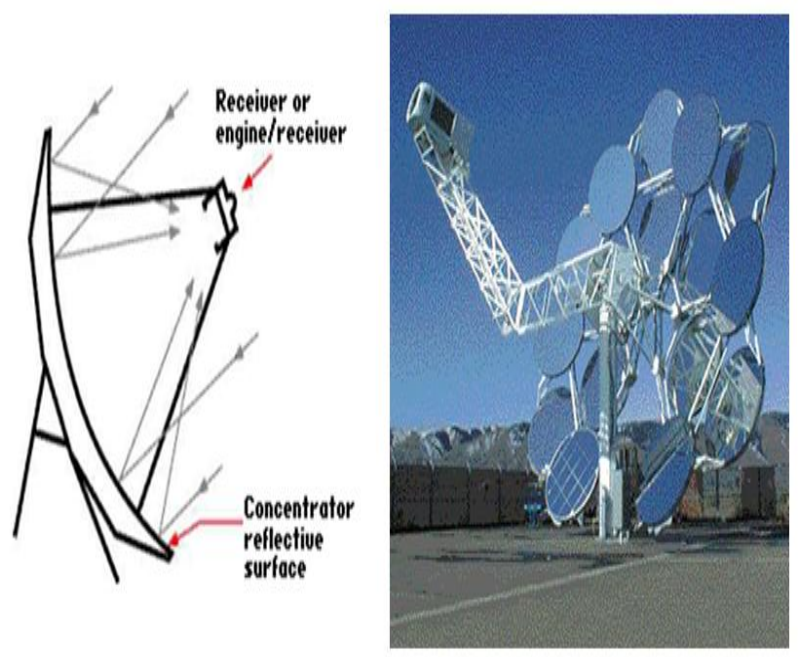

Fig 4.Crossection of parabolic dish[10]
Parabolic trough collector involves the most mature solar technology to generate heat up to $4000 \mathrm{C}$ for solar thermal electricity generation or process heat application. The application of the parabolic trough collectors are reported by Kalagirou [4] and Tian [5].Parabolic trough collectors are designed for a power range of 30 to $150 \mathrm{MW}$. It consists of a large array of parabolic trough reflectors (Fig-6 \& Fig-7) that reflect the sunlight to a black absorber tube that lies in the focus line. The main drawback of the system is that it cannot operate at diffuse light condition. Preheater/reheater is used to maintain continuous supply of steam. Parabolic trough collectors have one-axis tracking system that keeps the tube in the focus line during the day. The absorber tube is cooled by a heat transfer fluid (HTF), usually synthetic oil with temperature resistance up to $400 \mathrm{OC}$. The hot fluid is pumped to a heat exchanger/evaporator of a steam Rankin cycle (Fig-2) for steam and power generation [10]. The entire energy conversion process involves solar thermal conversant.
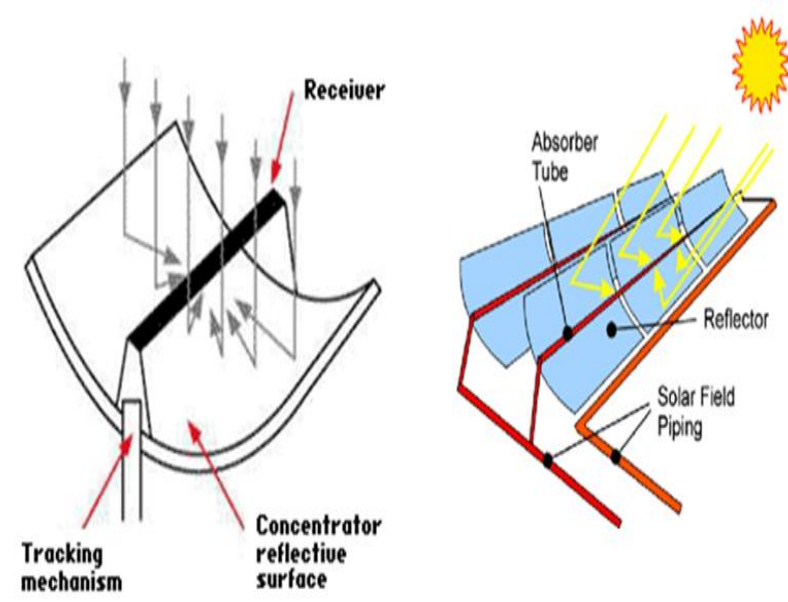

Fig 6.Crossection of parabolic trough[10]Fig 7 Solar collector assembly [9]

\section{Central tower power plants}

Central tower collector which consists of two axis tracking curved mirrors called heliostats that reflect sunlight as shown in (Fig-9\& Fig-10).Only beam radiation from the mirror is received and absorbed by a centrally placed receiver placed on the top of the tower. A receiver used is an intense black body absorber. Different absorber concepts like direct steam generating tubular receiver absorber, cavity absorber, open volumetric air receiver, molten salt receiver, focal absorbers have been tested. Usually, a conventional steam cycle power plant is connected for conversion of the heat to electricity. The temperature can reach up to $8000 \mathrm{C}$ to enhance steam cycle efficiency by the help of air system. 

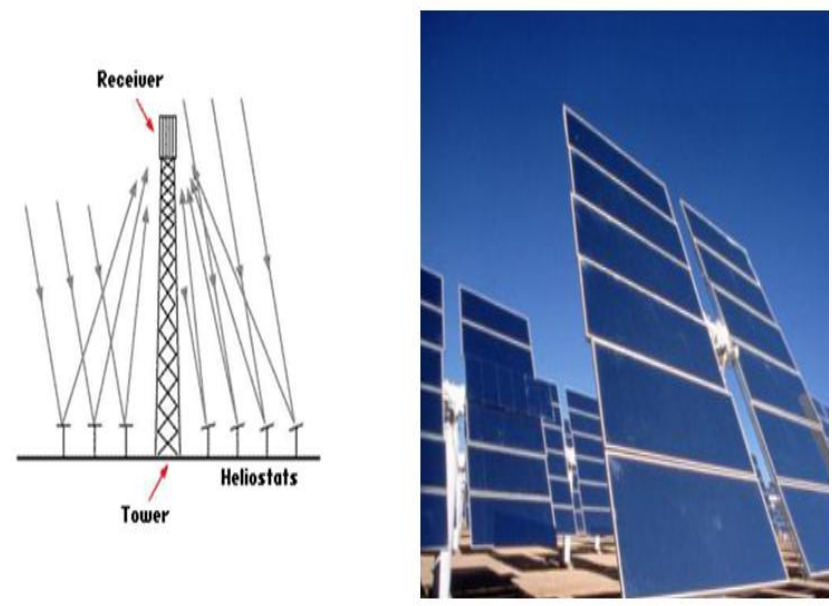

Fig-8 Power tower system [10]Fig 9. Heliostats

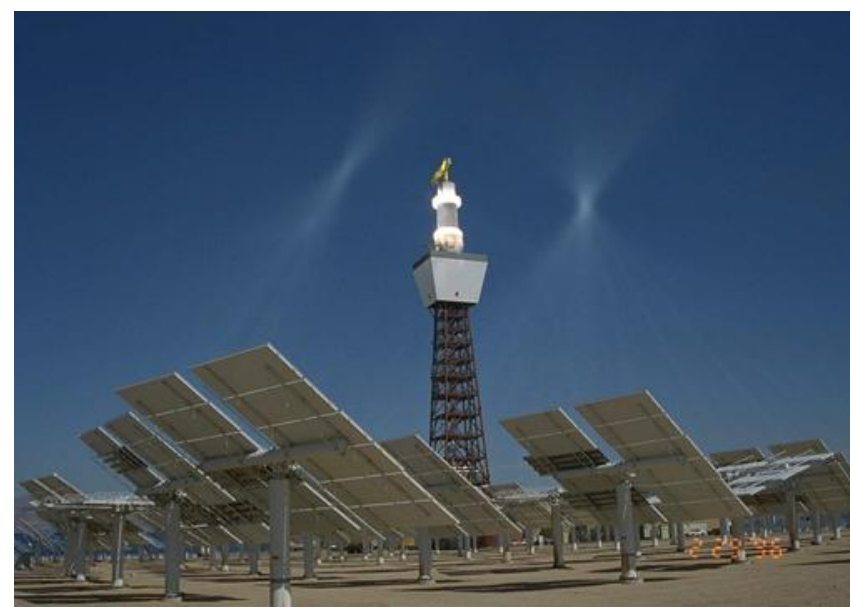

Fig 10.Power tower system with heliostats.(Source Internet)

\section{CALCULATION OF EFFICIENCY OF VARIOUS COLLECTORS\& RESULTS}

The heat generated in a collector $\mathrm{Q}$ is given by $\mathrm{Q}=(\alpha \tau)$ effective means absorb- loss of heat coefficient(Ul)----- (1)

Efficiency is given by

Efficiency $=\mathrm{Q} / \mathrm{S}$

Efficiency $=[(\alpha \tau)-\mathrm{Ul}] / \mathrm{S}(\mathrm{Ts}-\mathrm{Ta})$

Where,

$(\alpha \tau)=$ effective heat radiation absorbed

$\mathrm{Ul}=$ Heat loss coefficient from absorber

Ts=Solar Radiation temperature in

$\mathrm{Ta}=$ Atmospheric temperature in

$\mathrm{S}=$ Solar intensity in watt $/ \mathrm{m} 2$

For flat plate (Duffie \& Beckman, [1])

$\mathrm{Ts}=70^{\circ} \mathrm{C}=(70+273) \mathrm{K}=343 \mathrm{~K}$

$\mathrm{Ta}=25^{\circ} \mathrm{C}=(25+273) \mathrm{K}=298 \mathrm{~K}$

$\mathrm{Ul}=4$

$\mathrm{S}=700 \mathrm{watt} / \mathrm{m} 2$

$\mathrm{CR}$ (concentration ratio) $=1$

Turbine factor $\quad=0.342$

Turbo generator factor $=0.6$

Efficiency $=\left\{\left(\alpha^{*} \tau\right)-(\mathrm{UlS}) *(\mathrm{Ts}-\mathrm{Ta}) * 100\right\}$

$$
=(0.6-(4 / 700 * 45)) * 100=34.2 \%
$$

$$
\begin{aligned}
\text { Efficiency (Carnot) } & =\{(1-\mathrm{Ta} / \mathrm{Ts}) * 100\} \\
& =(1-(298 / 343)) * 100 \\
& =13.1 \%
\end{aligned}
$$

Efficiency $($ electrical $)=\{(\eta$ carnot $*$ Turbine factor $) * 100\}$

$$
\begin{aligned}
& =(0.131 * 0.342) * 100 \\
& =4.4 \%
\end{aligned}
$$

Efficiency (final) $\quad=\quad\{$ (turbogenerator factor*nelectrical $\left.)^{*} 100\right\}$

$$
\begin{aligned}
& =(0.6 * 4.4)=2.64 \% \sim \\
& =3 \%
\end{aligned}
$$

For Parabolic trough

$\mathrm{Ts}=300{ }^{\circ} \mathrm{C}=(300+273) \mathrm{K}=573 \mathrm{~K}$

$\mathrm{Ta}=25^{\circ} \mathrm{C}=(25+273) \mathrm{K}=298 \mathrm{~K}$

$\mathrm{Ul}=2.5$

$\mathrm{S}=800 \mathrm{watt} / \mathrm{m} 2$

$\mathrm{CR}($ concentration ratio $)=60($ Average value $)$

Turbine factor $\quad=0.342$

Turbo generator factor $=0.6$

Efficiency $\quad=\left\{\left(\alpha^{*} \tau\right)-(\mathrm{UlS}) *(\mathrm{Ts}-\mathrm{Ta}) * 100\right\}$

$$
=(0.68-(2.5 /(800 * 60) *(300-25))) * 100
$$$$
=66 \%
$$

Efficiency $($ Carnot $)=[\{1-(\mathrm{Ta} / \mathrm{Ts})\} * 100]$

$$
\begin{aligned}
& =(1-(298 / 573)) * 100 \\
& =47 \%
\end{aligned}
$$

Efficiency $($ electrical $)=\left\{\left(\eta \text { carnot }^{*} \text { Turbine factor }\right)^{*} 100\right\}$

$$
\begin{aligned}
& =(0.47 * 0.342) * 100 \\
& =16 \%
\end{aligned}
$$

Efficiency $($ final $)=\{($ turbo generator factor

*nelectrical)*100\}

$$
\begin{aligned}
& =(0.6 * 0.16) \\
& =9.6 \% \sim=10 \%
\end{aligned}
$$

For Parabolic dish

$\mathrm{Ts}=1000^{\circ} \mathrm{C}=(1000+273) \mathrm{K}=1273 \mathrm{~K}$

$\mathrm{Ta}=25^{\circ} \mathrm{C}=(25+273) \mathrm{K}=298 \mathrm{~K}$

$\mathrm{Ul}=2.5$

$\mathrm{S}=800 \mathrm{watt} / \mathrm{m} 2$

CR $($ concentration ratio $)=2.5$

Turbine factor $=0.342$

Turbo generator factor $=0.6$

Efficiency $=\{(\alpha * \tau)-(\mathrm{U} / \mathrm{S}) *(\mathrm{Ts}-\mathrm{Ta}) * 100\}$

$=(0.7-(2 /(900 * 200) *(1000-25))) * 100=68 \%$

Efficiency $($ Carnot $)=\left\{(1-(\mathrm{Ta} / \mathrm{Ts}))^{*} 100\right\}$

$$
\begin{aligned}
& =(1-(298 / 1273)) * 100 \\
& =76 \%
\end{aligned}
$$

Efficiency $($ electrical $)=\left\{\left(\eta \text { carnot }^{*} \text { Turbine factor }\right)^{*} 100\right\}$

$$
\begin{aligned}
& =(0.76 * 0.342) * 100 \\
& =26 \%
\end{aligned}
$$

Efficiency(final)

$=\{($ turbogeneratorfactor* $*$ electrical $) * 100\}$

$$
=(0.8 * 0.26)=20.8 \% \sim=21
$$

For Central Tower

$\mathrm{Ts}=1200^{\circ} \mathrm{C}=(1200+273) \mathrm{K}=1473 \mathrm{~K}$

$\mathrm{Ta}=25^{\circ} \mathrm{C}=(25+273) \mathrm{K}=298 \mathrm{~K}$

$\mathrm{Ul}=3$ 
$\mathrm{S}=900 \mathrm{watt} / \mathrm{m} 2$

$\mathrm{CR}($ concentration ratio $)=500$

Turbine factor $=0.342$

Turbo generator factor $=0.8$ for Sterling Engine

Efficiency $=\left\{\left(\alpha^{*} \tau\right)-(\mathrm{U} / \mathrm{S}) *(\mathrm{Ts}-\mathrm{Ta})\right\} * 100$

$=(0.72-(3 /(900 * 500) *(1200-25))) * 100$

$$
=71 \%
$$

Efficiency $($ Carnot $)=\left\{(1-(\mathrm{Ta} / \mathrm{Ts}))^{*} 100\right\}$

$$
\begin{aligned}
& =(1-(298 / 1473)) * 100 \\
& =79 \%
\end{aligned}
$$

Efficiency $($ electrical $)=\{(\eta$ carnot $*$ Turbine factor $) * 100\}$

$$
\begin{aligned}
& =(0.79 * 0.342) * 100 \\
& =27 \%
\end{aligned}
$$

Efficiency $\quad($ final $)=\quad\{$ (turbo $\quad$ generator factor*nelectrical $) * 100\}$

$$
=(0.6 * 0.27)=16.3 \% \sim=17 \%
$$

A comparison of efficiencies of various types of solar thermal power plant is shown in table 1 .

TABLE.1 Comparison of efficiencies of various types of solar thermal power plants

\begin{tabular}{|l|l|l|l|l|l|l|l|}
\hline $\begin{array}{l}\text { Type of } \\
\text { collector }\end{array}$ & $\alpha \zeta$ & $\mathrm{U}_{\mathrm{l}}$ & $\begin{array}{l}\text { Concentrator } \\
\text { ratio } \\
(\mathrm{CR})\end{array}$ & $\begin{array}{l}\text { Efficiency } \\
(\%)\end{array}$ & $\begin{array}{l}\text { Carnot } \\
\text { efficiency } \\
(\%)\end{array}$ & $\begin{array}{l}\text { Electrical } \\
\text { efficiency } \\
(\%)\end{array}$ & $\begin{array}{l}\text { Final } \\
\text { efficiency } \\
(\%)\end{array}$ \\
\hline FLAT PLATE & 0.60 & 4 & 1 & $34.2 \%$ & $13.1 \%$ & $4.4 \%$ & $3 \%$ \\
\hline $\begin{array}{l}\text { PARABOLIC } \\
\text { TROUGH }\end{array}$ & 0.68 & 2.5 & $40-80$ & $66 \%$ & $47 \%$ & $16 \%$ & $9.6 \%$ \\
\hline $\begin{array}{l}\text { PARABOLIC } \\
\text { DISH }\end{array}$ & 0.70 & 2.0 & $100-250$ & $68 \%$ & $76 \%$ & $26 \%$ & $21 \%$ \\
\hline $\begin{array}{l}\text { CENTRAL } \\
\text { TOWER }\end{array}$ & 0.72 & 3.0 & $200-700$ & $71 \%$ & $79 \%$ & $27 \%$ & $16.3 \%$ \\
\hline
\end{tabular}

From the above table it is clear that the central tower has higher electrical efficiency (27\%) followed by $26 \%$ in parabolic dish.

\section{CONCLUSION}

As solar thermal power plant is very popular now a days.It collects the solar radiation from a large area and concentrates it in to a smaller area and hence the losses are minimum. Among all the solar thermal technologies, central tower has the highest electrical efficiency of $27 \%$ followed by $26 \%$ in parabolic dish. Hence, wherever possible, central tower should be preferred to other solar thermal technologies.

\section{ACKNOWLEDGMENT}

The authors express their deep sense of gratitude to Dr. N.D Kaushika, Research Professor, ITER and the authorities of ITER, Siksha 'O' Anusandhan Deemed to be University, Bhubaneswar for providing facilities for the survey and research works.

\section{REFERENCES}

1. Duffie, J. A., \& Beckman, W. A. (1980). Solar engineering of thermal processes (Vol. 3). New York etc.: Wiley.

2. Qiblawey, H. M., \& Banat, F. (2008). Solar thermal desalination technologies. Desalination, 220(1), 633-644.

3. Garcia-Rodriguez, L., Palmero-Marrero, A. I., \& Gómez-Camacho, C. (2002). Comparison of solar thermal technologies for applications in seawater desalination. Desalination, 142(2), 135-142.

4. Kalogirou, S. (2003). The potential of solar industrial process heat applications. Applied Energy, 76(4), 337-361.

5. Tian, Y., \& Zhao, C. Y. (2013). A review of solar collectors and thermal energy storage in solar thermal applications. Applied Energy, 104, 538-553.

6. Kalogirou, S. A. (2004). Solar thermal collectors and applications. Progress in energy and combustion science, 30(3), 231-295.

7. Kuravi, S., Trahan, J., Goswami, D. Y., Rahman, M. M., \&Stefanakos, E. K. (2013). Thermal energy storage technologies and systems for concentrating solar power plants. Progress in Energy and Combustion Science, 39(4), 285-319.

8. Nixon, J. D., Dey, P. K., \& Davies, P. A. (2010). Which is the best solar thermal collection technology for electricity generation in north-west India? Evaluation of options using the analytical hierarchy process. Energy, 35(12), 5230-5240.

9. http://www.nrel.gov/csp/troughnet/solar_field.html.

10. Trieb, F., Langni $\beta$, O., \&Klai $\beta$, H. (1997). Solar electricity generation-a comparative view of technologies, costs and environmental impact. Solar Energy, 59(1), 89-99.

11. http://www.usdebtclock.org/energy.html. 